\title{
Hubungan Aktivitas Fisik dan Kebiasaan Konsumsi Fast Food dengan Status Gizi Lebih Remaja SMA Labschool Kebayoran Baru Jakarta Selatan Tahun 2016
}

\author{
Siti Riptifah Tri Handari ${ }^{1}$, Tri Loka ${ }^{2}$ \\ ${ }^{1,2}$ Program Studi Kesehatan Masyarakat, Fakultas Kedokteran dan Kesehatan,Universitas Muhammadiyah \\ Jakarta \\ J1. KH. Ahmad Dahlan, Cireundeu, Ciputat, Kota Tangerang Selatan, Banten 15419 \\ Email: ndari_drh@yahoo.co.id
}

\begin{abstract}
ABSTRAK
Masa Remaja merupakan masa transisi antara masa kanak - kanak dan masa dewasa, dan melibatkan perubahan fisik maupun emosional, seiring meningkatnya kemandirian dan semakin banyaknya pilihan pribadi. Salah satunya adalah pilihan makanan yang akan berdampak pada asupan dan status gizi. Prevalensi gizi lebih relatif lebih tinggi pada remaja perempuan $(1,5 \%)$ dibanding dengan remaja laki-laki (1,3\%). Sedangkan Provinsi dengan prevalensi gemuk tertinggi adalah DKI Jakarta $(4,2 \%)$. Tujuan penelitian ini untuk mengetahui hubungan antara aktfitas fisik dan kebiasaan konsumsi makanan fast food dengan status gizi lebih remaja di SMA Labschool Kebayoran Baru Tahun 2016. Penelitian ini dilaksanakan pada bulan Agustus 2016 dengan menggunakan desain cross sectional. Sampel diambil dengan teknik accidental sampling sebanyak 111 responden. Analisis dilakukan secara bivariat melalui uji chi-square. Sebanyak 58,6\% siswa mengalami status gizi lebih. Hasil uji bivariat menunjukan bahwa adanya hubungan antara Umur $(\mathrm{p}=0,0005)$, Jenis Kelamin $(\mathrm{p}=0,038)$, Pendidikan Ibu ( $\mathrm{p}=0,0005)$, Pekerjaan Ibu ( $\mathrm{p}=0,0005)$, Pekerjaan Ayah ( $\mathrm{p}=0,025)$, Keibasaan Olahraga ( $\mathrm{p}=0,0005)$, Kebiasaan Konsumsi Fast Food ( $\mathrm{p}=0,0005)$ dengan Status Gizi Lebih pada remaja $(\mathrm{p} \leq$ 0,05). Saran untuk pihak sekolah, puskesmas dan keluarga yaitu mengadakan sosialisasi mengenai pedoman umum gizi seimbang (PUGS) mengenai porsi makan dan bahan makanan yang baik, serta sesuai untuk dikonsumsi oleh remaja dengan kerangka penyuluhan yang modern dan menggunakan berbagai istilah yang dekat dengan kehidupan remaja sehari - hari agar pesan mudah dipahami dan membuat siswa tertarik untuk menjalani PUGS terutama di Sekolah. Selain itu, OSIS, UKS dan PMR SMA Labschool Kebayoran Baru dapat melakukan kegiatan "sadar gizi" yang didalamnya terdapat kegiatan - kegiatan yang berhubungan dengan gizi dan aktivitas fisik serta juga dapat membuat majalah dinding (mading) tiap bulannya yang bertemakan gizi dan kesehatan jasmani.
\end{abstract}

Kata kunci: Aktivitas Fisik, Fast Food, Status Gizi

\section{The Relationship of Physical Activity Habits and Comsumption Habits of Fast Food with Adolescent Overweight Status Labschool High School Kebayoran Baru, South Jakarta 2016}

\begin{abstract}
Adolescence is a transitional period between childhood and adulthood, and involves both physical and emotional change, with increasing independence and increasing personal preferences. One of them is the choice of food that will affect the intake and nutritional status. The prevalence of nutrition is relatively higher in girls $(1.5 \%)$ than in boys $(1.3 \%)$. While the province with the highest prevalence of fat was DKI Jakarta (4.2\%) The purpose of this study to determine the relationship between physical activity habits and consumption habits of fast food with adolescent overweight status labschool high school Kebayoran Baru, South Jakarta 2016. This study was conducted in August 2016 by using cross sectional design. Samples were taken by accidental sampling technique as much as 111 respondents The analysis was performed using bivariate with chi-square test. . A total of $58.6 \%$ of students is overweight. The result of bivariate test showed that there was a relationship between age
\end{abstract}


$(\mathrm{p}=0.0005)$, gender $(\mathrm{p}=0,038)$, maternal education $(\mathrm{p}=0.0005)$, maternal job $(\mathrm{p}=0,0005)$, dad work $(\mathrm{p}=$ $0.025)$, Sports Feelings $(\mathrm{p}=0.0005)$, Fast Food Consumption Habit $(\mathrm{p}=0.0005)$ with adolescents overweight status $(\mathrm{p} \leq 0.05)$. Suggestions for the schools, health centers and family is the socialization of the general guidelines of balanced nutrition (PUGS) on food portions and good foodstuff and suitable for consumption by teenagers with a modern extension framework and use a variety of terms are close to the teenager's daily lifeso that the message is easy to understand and make students interested in establishing PUGS especially in schools. In addition, Intra-School Students Organization (OSIS), School Health Unit(UKS) and Red Cross Teen (PMR) Labschool High School, Kebayorab Baru can conduct "aware of nutrition" in which there are activities related to nutrition and physical activity, and also can create wall magazine (Mading) each month with the theme of nutrition and physical health.

Keywords: Physical Activity, Fast Food, Nutritional Status

\section{Pendahuluan}

Masa remaja adalah masa transisi antara masa kanak - kanak dan masa dewasa yang melibatkan perubahan fisik maupun emosional, seiring meningkatnya kemandirian dan semakin banyaknya pilihan pribadi. Pilihan makanan berdampak pada asupan dan status gizi mereka. ${ }^{1}$

Perubahan - perubahan yang terjadi pada remaja cenderung akan menimbulkan berbagai permasalahan dan perubahan perilaku di kehidupan remaja. Salah satu bentuk perubahan perilaku pada masa remaja adalah perubahan perilaku makan baik mengarah keperilaku makanan yang sehat ataupun cenderung mengarah kepada perilaku makan yang tidak sehat. ${ }^{2}$ Masalah gizi pada remaja muncul dikarenakan perilaku gizi yang salah, yaitu ketidakseimbangan antara konsumsi gizi dengan kecukupan gizi dan aktifitas. Salah satu masalah gizi pada remaja adalah gizi lebih yaitu ditandai dengan berat badan yang relatif berlebihan bila dibandingkan dengan usia atau tinggi badan remaja sebaya, sebagai akibat terjadinya penimbunan lemak yang berlebihan dalam jaringan lemak tubuh. ${ }^{3}$
Berdasarkan hasil laporan Riskesdas Tahun 2010, prevalensi gizi lebih pada kelompok usia diatas 15 tahun mencapai $19,1 \%$, sedangkan pada remaja umur $16-18$ tahun secara nasional yaitu $1,4 \%$. Prevalensi gizi lebih relatif lebih tinggi pada remaja perempuan $(1,5 \%)$ dibanding dengan remaja laki-laki (1,3\%).4 Berdasarkan tempat tinggal, prevalensi gizi lebih pada remaja di Perkotaan $(1,8 \%)$ lebih tinggi dari pada di Pedesaan $(0,9 \%)$.

Di Indonesia prevalensi gemuk pada remaja umur 16 - 18 tahun sebanyak $7,3 \%$ yang terdiri dari 5,7\% gemuk dan 1,6\% obesitas. Sedangkan prevalensi gemuk pada remaja umur 13-15 tahun di Indonesia sebesar $10,8 \%$, terdiri dari $8,3 \%$ gemuk dan $2,5 \%$ obesitas. Sebanyak 13 provinsi dengan prevalensi gemuk yang tinggi secara nasional yaitu DKI Jakarta, Jawa Timur, Kepulauan Riau, Sumatera Selatan, Kalimantan Barat, Bangka Belitung, Bali, Kalimantan Timur, Lampung, Sulawesi Utara dan Papua. Provinsi dengan prevalensi gemuk yang tetinggi terdapat di Wilayah DKI Jakarta $(4,2 \%){ }^{5}$ 
Perilaku makan tidak baik adalah kebiasaan mengkonsumsi makanan yang tidak memberi semua zat-zat gizi esensial seperti karbohidrat, lemak dan protein yang dibutuhkan dalam metabolisme tubuh. Perilaku makan tidak baik seperti makan yang tidak teratur baik waktu ataupun jenis makanan, diet penurunan berat badan, binge eating, kebiasaan makan pada malam hari dapat merusak kesehatan dan keseejahteraan psikologis individu. ${ }^{6}$

Fast food dapat diartikan sebagai makanan yang dapat dihidangkan dan dikonsumsi dalam waktu seminimal mungkin atau juga dapat diartikan sebagai makanan yang dikonsumsi secara cepat. Pada umumnya komposisi fast food mengandung lebih tinggi energi, garam dan lemak termasuk kolesterol dan hanya sedikit mengandung serat. ${ }^{7}$

Berdasarkan Riskesdas 2013, diketahui proporsi aktiviats fisik tergolong kurang aktif secara umum adalah $26,1 \%$. DKI Jakarta termasuk ke dalam provinsi dengan penduduk aktivitas fisik tergolong kurang aktif berasa di atas rata - rata Indonesia dan menduduki posisi lima tertinggi dengan presentasi 44,2\%. Aktivitas fisik sebaiknya dilakukan secara teratur sebanyak 3 kali atau lebih dalam seminggu dengan tingkatan olahraga sedang samapai berat. Aktivitas fisik sebaiknya dilakukan minimal 30 menit setiap hari.

Berdasarkan data di atas, peneliti tertarik melakukan penelitian untuk mengetahui Hubungan Aktivitas Fisik dan Kebiasaan Konsumsi Fast Food dengan Status Gizi Lebih
Remaja di SMA Labschool Kebayoran Baru Jakarta Selatan Tahun 2016.

\section{Metode Penelitian}

Penelitian ini merupakan penelitian deskriptif analitik dengan menggunakan pendekatan cross sectional. Penelitian ini dilakukan di SMA Labschool Kebayoran Baru pada bulan Agustus 2016. Pemilihan tempat berdasarkan hasil observasi bahwa SMA Labschool Kebayoran Baru merupakan sekolah yang berada di kawasan elit dengan rata - rata penduduk memiliki tingkat pendapatan dan pendidikan tinggi, siswa siswi di SMA Labschool Kebayoran Baru juga memiliki postur tubuh tinggi dan besar baik laki - laki maupun perempuan. Menurut guru bidang Bimbingan dan Konseling (BK) bahwa siswa - siswi yang mengalami status gizi lebih ada yang aktif dalam akademik dan tidak aktif dalam olahraga atau kurang gerak. Sampel yang digunakan yaitu kelas XI dengan jumlah sampel minimal adalah 101, kemudian untuk menghindari bias maka ditambah 10\%, sehingga sampel penelitian adalah $111 \%$ yang diambil secara accidental sampling. Alat pengumpul data menggunakan kuesioner.

Analisis pada penelitian ini dilakukan menggunakan perangkat lunak statistik dengan dua tahap, yaitu analisis univariat untuk mengetahui distribusi frekuensi variabel dependen (Status Gizi Lebih) dan variabel independen (Jenis Kelamin, Umur, Pendidikan Orang Tua, Pekerjaan Orang Tua, Waktu Tidur, Durasi Menonton TV/ Komputer, Kebiasaan Berolahraga, Konsumsi Fast Food), 
dan yang kedua adalah analisis bivariat untuk mengetahui hubungan antara variabel independen terhadap variabel dependen. Analisis bivariat dilakukan dengan uji chisquare $\left(\mathrm{X}^{2}\right)$. pengukuran variabel dependen (Status Gizi Lebih) dilakukan dengan mengukur berat badan dan tingi badan menggunakan timbangan injak SECCA dengan ketelitian $0,1 \mathrm{~kg}$ dan microtoise dengan ketelitian $0,1 \mathrm{~cm}$ untuk variabel umur, jenis kelamin, pekerjaan orang tua, pendidikan orang tua diukur dengan kuesioner. Untuk variabel durasi menonton TV/komputer dan aktivitas fisik diukur dengan kuesinoer yang mengacu pada aturan Depkes 2002. Sedangkan untuk variabel konsumsi fast food diukur dengan menggunakan kuesioner SQ-FFQ (Semi Quantitative - Food Frequency Questionnaire).

\section{Hasil}

Berdasarkan tabel 1 dapat diketahui bahwa perempuan dua kali lebih banyak dari laki-laki $(68,5 \%: 31,5 \%)$, sedangkan untuk kelompok umur paling banyak adalah yang berumur 15 tahun $(59,4 \%)$. Hasil analisis pada variabel pendidikan orang tua, $71,2 \%$ pendidikan ibu adalah perguruan tinggi, sedangkan untuk pendidikan ayah 98,2\% perguruan tinggi. Untuk variabel pekerjaan orang tua, $62,2 \%$ ibu sebagai ibu IRT, dan 73,9 ayah bekerja sebagai pegawai swasta.
Tabel 1. Karakteristik Responden Berdasarkan Kelompok Umur, Jenis Kelamin, Pendidikan Orangtua, Dan Perkerjaan Orangtua

\begin{tabular}{|c|c|c|}
\hline Variabel & $\mathbf{n}$ & $\%$ \\
\hline \multicolumn{3}{|l|}{ Jenis kelamin } \\
\hline Laki - laki & 35 & 31,5 \\
\hline Perempuan & 76 & 68,5 \\
\hline \multicolumn{3}{|l|}{ Kelompok umur } \\
\hline 15 & 66 & 59,4 \\
\hline 16 & 45 & 40,6 \\
\hline \multicolumn{3}{|l|}{ Pendidikan Ibu } \\
\hline SMA & 32 & 28,8 \\
\hline Perguruan Tinggi & 79 & 71,2 \\
\hline \multicolumn{3}{|l|}{ Pendidikan Ayah } \\
\hline SMA & 2 & 1,8 \\
\hline Perguruan Tinggi & 109 & 98,2 \\
\hline \multicolumn{3}{|l|}{ Pekerjaan Ibu } \\
\hline IRT & 69 & 62,2 \\
\hline PNS & 14 & 12,6 \\
\hline Peg.Swasta & 16 & 14,4 \\
\hline Wiraswasta & 12 & 10,8 \\
\hline \multicolumn{3}{|l|}{ Pekerjaan Ayah } \\
\hline Pensiunan & 11 & 9,9 \\
\hline Peg.swasta & 82 & 73,9 \\
\hline Wiraswasta & 10 & 9 \\
\hline PNS & 8 & 7,2 \\
\hline
\end{tabular}

Berdasarkan tabel 2. Dapat diketahui bahwa hasil analisis menujukkan sebesar $91 \%$ remaja SMA Labschool Kebayoran Baru mempunyai durasi $\leq 8$ jam/hari, sedangkan remaja yang memiliki durasi tidur $>8 \mathrm{jam} / \mathrm{hari}$ 9\%. Hasil analisis meunjukkan reponden yang mempunyai kebiasaan menonton TV/komputer/video games lebih dari 2 jam perhari sebanyak $75,7 \%$ responden dan yang kurang dari 2 jam sebanyak 24,3\% responden. Hasil analisis menunjukkan bahwa $60,4 \%$ responden melakukan olahraga $<3$ kali perminggu dan 49,6\% responden lainnya melakukan olahraga $\geq 3$ kali perminggu. 
diketahui hasil analisis menunjukkan bahwa $60,4 \%$ responden melakukan olahraga $<3$ kali perminggu dan 49,6\% responden lainnya melakukan olahraga $\geq 3$ kali perminggu.

Tabel 2. Karakteristik Responden Berdasarkan Status Gizi, Durasi Tidur, Durasi Menonton, Kebiasaan Olahraga dan Fast Food

\begin{tabular}{lll}
\hline Variabel & n & \% \\
\hline Status gizi & 2 & 1,8 \\
Sangat Kurus & 5 & 4,5 \\
Kurus & 39 & 35,1 \\
Normal & 60 & 54,1 \\
Overweight & 5 & 4,5 \\
Obesitas & & \\
Durasi tidur & 101 & 91 \\
$\leq 8$ jam/hari & 10 & 9 \\
$>8$ jam/hari & & \\
Durasi menonton TV & 27 & 24,3 \\
$\leq 2$ jam/hari & 84 & 75,7 \\
$>2$ jam/hari & & \\
Kebiasaan berolahraga & & 60,4 \\
$<3$ kali perminggu & 67 & 39,6 \\
$\geq 3$ kali perminggu & 44 & \\
Fast Food & & 64,9 \\
$\leq 3$ kali perminggu & 39 & 72 \\
$>3$ kali perminggu & & \\
\hline
\end{tabular}

Hasil analisis statistik menunjukkan bahwa terdapat hubungan yang signifikan antara umur dengan status gizi lebih remaja $\mathrm{p}=0,0005(\mathrm{p}<0,05)$. Dari hasil statistik tersebut terdapat kecenderungan siswa yang berumur $>15$ tahun yang mengalami gizi lebih $(84,4 \%)$ berpotensi hampir 8 kali lebih besar mengalami gizi lebih dibandingan siswa yang berumur $\leq 15$ tahun. Pada variabel jenis kelamin, hasil analisis statistik menunjukkan bahwa adanya hubungan yang signifikan antara jenis kelamin dengan status gizi lebih remaja $\mathrm{p}=0,038(\mathrm{p}<0,05)$. Dari hasil statistik terebut terdapat kecendurangan anak laki - laki yang mengalami status gizi lebih $(74,3)$ berpotensi 7 kali lebih bear mengalami gizi lebih dibandingkan dengan responden perempuan. Hasil analisis statistik menunjukkan bahwa terdapat hubungan yang signifikan antara pendidikan ibu dengan status gizi lebih remaja $\mathrm{p}=0,0005 \quad(\mathrm{p}<0,05)$, responden yang mempunyai ibu berpendidikan tinggi yang mengalami status gizi lebih $(79,7 \%)$ memiliki potensi 59 kali lebih besar berstatus gizi lebih dibandingkan dengan responden yang memilki ibu berpendidikan rendah.

Hasil analisis statistik menunjukkan bahwa terdapat hubungan yang signifikan antara pekerjaan ibu dengan status gizi lebih remaja $\mathrm{p}=0,0005(\mathrm{p}<0,05)$, dari hasil statistik terebut terdapat kecendurangan siswa yang memiliki ibu bekerja dengan status gizi lebih $(83,3 \%)$ berpotensi hampir 7 kali lebih besar mengalami gizi lebih dibandingkan dengan ibu yang tidak bekerja. Hasil analisis statistik menunjukkan bahwa terdapat hubungan yang signifikan antara pekerjaan ayah dengan status gizi lebih remaja $\mathrm{p}=0,025(\mathrm{p}<0,05)$. Hasil uji statistik menunjukkan bahwa terdapat hubungan yang signifikan antara kebiasaan olaharaga dengan status gizi lebih remaja $\mathrm{p}=0,0005 \quad(\mathrm{p}<0,05) . \quad$ Hasil tersebut menunjukkan bahwa adanya kecenderungan pada siswa dengan kebiasaan olahraga $<3 \mathrm{x} /$ minggu dengan yang memiliki statusgizi lebih $(88,1 \%)$ berpotensi hampir 6 kali lebih besar untuk memiliki status gizi lebih 
dibandingkan dengan remaja yang meiliki kebiasaan berolahraga $\geq 3 \mathrm{x} /$ minggu. Kemudian untuk variabel konsumsi fast food, Hasil uji statistik menunjukkan bahwa terdapat hubungan yang signifikan antara konsumsi fast food dengan status gizi lebih remaja $\mathrm{p}=0,0005$ $(\mathrm{p}<0,05)$. Hasil tersebut menunjukkan bahwa ada kecenderungan pada siswa dengan konsumsi fast foot $>3 \mathrm{x} /$ minggu yang memiliki gizi lebih $(76,4 \%)$ berpotensi hampir 19 kali lebih besar memiliki status gizi lebih dibandingkan dengan siswa yang mengkonsumsi fast food $\leq 3 \mathrm{x} /$ minggu.

Tabel 3. Hubungan Karakteristik Responden Dengan Status Gizi Lebih Remaja

\begin{tabular}{|c|c|c|c|}
\hline Variabel & Nilai $p$ & OR & CI (95\%) \\
\hline \multicolumn{4}{|l|}{ Kelompok umur } \\
\hline 15 & 0,0005 & 7,841 & $3,052-$ \\
\hline 16 & & & 20.149 \\
\hline \multicolumn{4}{|l|}{ Jenis kelamin } \\
\hline Laki - laki & 0,038 & 7,061 & $3,116-$ \\
\hline Perempuan & & & 12,752 \\
\hline \multicolumn{4}{|l|}{ Pendidikan Ibu } \\
\hline SMA & 0,0005 & 59,063 & $12,752-$ \\
\hline Perguruan Tinggi & & & 273,559 \\
\hline \multicolumn{4}{|l|}{ Pendidikan Ayah } \\
\hline SMA & 0,510 & - & \\
\hline \multicolumn{4}{|l|}{ Perguruan Tinggi } \\
\hline \multicolumn{4}{|l|}{ Pekerjaan Ibu } \\
\hline Tidak bekerja & 0,0005 & 6,5 & $2,537-$ \\
\hline Bekerja & & & 16,653 \\
\hline \multicolumn{4}{|l|}{ Pekerjaan Ayah } \\
\hline Tidak Bekerja & 0,025 & 7,841 & $0,015-$ \\
\hline Bekerja & & & 0,991 \\
\hline \multicolumn{4}{|l|}{ Durasi tidur } \\
\hline$\leq 8 \mathrm{jam} / \mathrm{hari}$ & 0,191 & - & \\
\hline \multicolumn{4}{|l|}{$>8 \mathrm{jam} / \mathrm{hari}$} \\
\hline \multicolumn{4}{|l|}{$\begin{array}{l}\text { Durasi menonton } \\
\text { TV }\end{array}$} \\
\hline$\leq 2 \mathrm{jam} / \mathrm{hari}$ & 0,74 & 6,53 & \\
\hline$>2$ jam/hari & & & \\
\hline
\end{tabular}

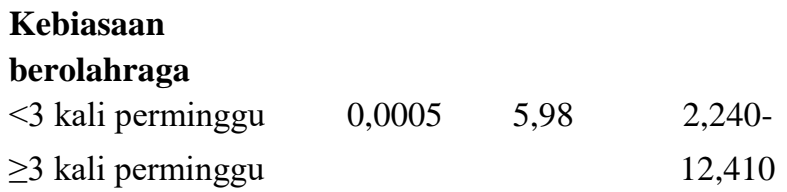

Fast Food

$\leq 3$ kali perminggu $\quad 0,0005 \quad 18,93 \quad 6,934-$

$>3$ kali perminggu $\quad 51,724$

\section{Pembahasan}

Berdasarkan hasil analisis bivariat menunjukan bahwa adanya hubungan antara variabel umur dengan status gizi lebih remaja $(p<0,05)$. Hal ini sejalan dengan teori yang menyatakan bahwa anak yang mengalami obesitas cenderuk akan menjadi obesitas pada saat remaja dan dewasa serta dapat lanjut ke masa lansia. $^{8}$ Dalam teori lain juga menyatakan bahwa dalam keadaan normal apabila kesehatan dalam keadaan baik terjadi keseimbangan antara konsumsi dan kebutuhan zat gizi maka berat badan akan berkembang mengikuti pertambahan umur, yang digunakan sebagai salah satu cara pengukuran status gizi dan indeks BB/U. ${ }^{9}$ Hasil ini tidak sejalan dengan penelitian yang dilakukan Widywati 2014 di Yogyakarta yang menunjukkan tidak adanya hubungan antara umur dan kejadian gizi lebih pada remaja.

Pada variabel jenis kelamin hasil analisis bivariat menunjukan bahwa ada hubungan yang signifikan antara jenis kelamin dengan status gizi lebih $(\mathrm{P}<0,05)$. Jenis kelamin lakilaki berpeluang lebih besar untuk memiliki gizi lebih. Sehingga hal ini tidak sejalan dengan teori yang menyatakan bahwa Jenis kelamin menetukan kebutuhan gizi seseorang. Status gizi gemuk (obesitas dan overweight) lebih sering terjadi pada wanita dibandingkan laki -

Siti Riptifah Tri Handari dan Tri Loka, Hubungan Aktivitas Fisik dan Kebiasaan Konsumsi Fast Food dengan Status Gizi Lebih Remaja SMA Labschool Kebayoran Baru Jakarta Selatan Tahun 2016 
laki. Pria lebih banyak membutuhkan energi dan protein daripada wanita. Hal ini disebabkan pria lebih banyak melakukan aktivitas fisik dibandingkan wanita. ${ }^{10}$ Akan tetapi penelitian ini sejalan dengan yang dilakukan oleh Utami, yaitu menunjukkan adanya hubungan yang signifikan antara jenis kelamin dengan status gizi lebih remaja. Perbedaan jenis kelamin juga dapat dihubungkan dengan body image. ${ }^{11}$

Hasil analisis uji statistik menunjukkan bahwa adanya hubungan yang signifikan antara tingkat pendidikan ibu dengan status gizi remaja $(\mathrm{p}<0,05)$. Hal ini didukung dengan kecenderungan bahwa remaja yang berstatus gizi alebih mempunyai ibu dengan tingkat pendidikan tinggi $(79,8 \%)$. Penelitian ini sejalan dengan teori Hidayat 1980 yang mengatakan bahwa Tingkat pendidikan turut mempengaruhi pola konsumsi makan melalui cara pemilihan bahan makanan dalam hal kualitas dan kuantitas dibandingkan orang tua berpendidikan rendah. Partisipasi orang tua dalam pelaksanaan pendidikan berpengaruh positif terhadap prestasi belajar murid dan menunjukkan semakin tinggi keterlibatan dan kepedulian terhadap masalah-masalah pendidikan di sekolah. Penelitian ini sejalan dengan penelitian yang dilakukan oleh Utami yaitu adanya hubungan antara tingkat pendidikan ibu dengan status gizi remaja. ${ }^{11}$ Namun penelitian ini tidak sejalan dengan penelitian yang dilakukan oleh Rahayuningtias, hasil uji statistiknya menunjukkan tidak ada hubungan yang signifikan antara pendidikan ibu dengan status gizi lebih. ${ }^{12}$

Pada hasil uji statistik menunjukkan bahwa tidak terdapat hubungan yang signifikan antara tingkat pendidikan ayah dengan status gizi remaja, namun pada penelitian ini ditemukan kecenderungan bahwa pada remaja yang berstatus gizi lebih banyak yang mempunyai ayah tingkat pendidikannya tinggi $(57,8 \%)$. Penelitian ini sejalan dengan penelitian yang dilakukan oleh Rahayuningtyas dan Utami yang menunjukkan tidak adanya hubungan yang signifikan antara tingkat pendidikan ayah dengan status gizi remaja. $^{11,12}$

Berdasarkan hasil uji statistik, jenis pekerjaan ibu mempunyai hubungan yang signifikan dengan status gizi remaja $(p<0,05)$. Diketahui bahwa proporsi gizi lebih banyak dialami oleh remaja yang mempunyai ibu yang bekerja $(83,3 \%)$, yang memiliki peluang 6,5 kali lebih besar berstatus gizi lebih adalah responden yang ibunya memiliki pekerjaan. Peneilitian ini sejalan dengan yang dilakukan oleh Utami, yaitu adanya hubungan yang signifikan antara jenis pekerjaan ibu dengan status gizi remaja. ${ }^{11}$ Namun penelitian ini tidak sejalan dengan penelitian yang dilakukan oleh Rahayuningtyas dan Hayati yang menunjukkan tidak adanya hubungan yang signifikan antara pekerjaan ibu dengan status gizi remaja. ${ }^{12}$

Berdasarkan hasil uji statistik menunjukkan bahwa adanya hubungan yang signifikan antara pekerjaan ayah dengan status gizi anak $\mathrm{P}<0,05)$. Diketahui bahwa proporsi gizi lebih yang memiliki ayah bekerja (55\%). 
Namun penelitian ini tidak sejalan dengan hasil penelitian yang dilakukan oleh Utami yaitu menunjukkan bahwa tidak adanya hubungan yang signifikan antara pekerjaan ayah dengan status gizi remaja. ${ }^{11}$

Hasil uji statistik mengenai pekerjaan orang tua baik ibu atau ayah sejalan dengan teori yang menyatakan bahwa peningkatan pendapatan juga dapat mempengaruhi pemilihan jenis dan jumlah makanan yang dikonsumsi. Peningkatan kemakmuran di masyarakat yang diikuti oleh peningkatan pendidikan dapat mengubah gaya hidup dan pola makan dari pola makan tradisional ke pola makan makanan praktis dan siap saji yang dapat menimbulkan mutu gizi yang tidak seimbang. Pola makan praktis dan siap saji terutama terlihat di kota-kota besar di Indonesia, dan jika dikonsumsi secara tidak rasional akan menyebabkan kelebihan masukan kalori yang akan menimbulkan obesitas seperti pada Virgianto dan Purwaningsih, 2006.

Berdasarkan hasil uji statistik diketahui bahwa durasi tidur tidak mempunyai hubungan signifikan dengan status gizi remaja. Namun terdapat kecenderungan bahwa remaja yang mengalami gizi lebih yang memiliki durasi tidur cukup. Hasil penelitian ini sejalan dengan penelitian (Utami, 2012) tidak terdapat hubungan yang signifikan antara durasi tidur dengan status gizi remaja lebih dapat disebabkan oleh proporsi remaja yang tidak jauh berbeda antara kategori durasi tidur. Hal ini disebabkan karena siswa menghabiskan waktu sedikitnya enam jam untuk belajar disekolah dan melanjutkan kegiatan belajar ditempat les pada sore hari.

Hasil uji statistik menunjukkan bahwa durasi menonton TV/ Komputer/bermain video games mempunyai hubungan yang signifikan dengan status gizi remaja. Hasil penelitian ini sejalan dengan ditemukan oleh Samosir 2008 yang menemukan hubungan yang signifikan anatara durasi menonton TV/ Komputer/ bermain video games dengan status gizi remaja. Namun penelitian yang dilakukan oleh Utami dan Mardhatillah menunjukkan bahwa tidak ada hubungan yang signifkan antara kebiasaan menonton TV/ komputer/ bermain video games dengan status gizi remaja. ${ }^{12,13}$ Namun Beberapa penelitian secara konsisten menyebutkan bahwa resiko overweight meningkat dengan bertambahnya durasi menonton TV. ${ }^{14}$

Berdasarkan hasil uji statistik diketahui bahwa ada hubungan yang signifikan antara kebiasaan olahraga dengan status gizi remaja $(p<0,05)$. Hasil penelitian yang sama juga ditemukan oleh Ortega dan Patrick menemukan hasil berhubungan antara aktivitas fisik kebiasaan olahraga dengan status gizi remaja. ${ }^{15,16}$ Namun, berbeda dengan hasil dari Utami ditemukan bahwa tidak ada hubungan yang signifikan antara kebiasaan berolahraga dengan status gizi remaja. ${ }^{11}$

Berdasarkan hasil uji statistik diketahi bahwa terdapat hubungan yang signifikan antara konsumsi fast food dengan status gizi lebih remaja $(\mathrm{p}<0,05)$. Hal ini sejalan dengan teori yang mengatakan bahwa Kehadiran fast food dalam industri makanan di Indonesia juga 
bisa mempengaruhi pola makan kaum remaja di kota. Khususnya bagi remaja tingkat menengah keatas, restoran, fast food ditawarkan dengan harga yang terjangkau dengan kantong mereka, sevisnya cepat, dan jenis makanannya memenuhi selera. Fast food adalah gaya hidup remaja kota. ${ }^{17}$ Kegemaran pada makanan siap saji modern yang mengandung tinggi kalori bila dikonsumsi dalam jangka waktu yang lama, pada akhirnya akan mengarahkan remaja ke perubahan patologis yang terlalu dini. ${ }^{8}$

\section{Kesimpulan dan Saran}

Berdasarkan hasil penelitian dan pembahasan pada bab sebelumnya, maka dapat disimpulkan bahwa gambaran distribusi status gizi lebih pada siswa di SMA Labschool Kebayoran Baru lebih tinggi (54,1\%) dibanding dengan siswa yang berstatus gizi normal $(45,9 \%)$. Hasil uji statistik menunjukan bahwa adanya hubungan yang signifikan antara variabel umur, jenis kelamin, pendidikan ibu, pekerjaan ibu, pekerjaan ayah, kebiasaan olahraga dan konsumsi fast food terhadap status gizi lebih $(\mathrm{p}<0,05)$.

Dengan adanya penelitian ini, dapat menjadi awal untuk menjalankan kerjasama dari pihak universitas dengan pihak sekolah SMA Labschool untuk menjalin kerjasama mengenai penyuluhan kesehatan mengenai gizi. Berdasarkan hasil penelitian ini, maka pihak sekolah terutama bagian UKS mengadakan sosialisasi mengenai pedoman umum gizi seimbang (PUGS) mengenai porsi makan dan bahan makanan yang baik, serta sesuai untuk dikonsumsi oleh remaja dengan kerangka penyuluhan yang modern dan menggunakan berbagai istilah yang dekat dengan kehidupan remaja sehari - hari agar pesan mudah dipahami dan membuat siswa tertarik untuk menjalani PUGS terutama di sekolah. Selain itu, OSIS, UKS dan PMR SMA Labschool Kebayoran Baru dapat melakukan kegiatan "sadar gizi" yang didalamnya terdapat kegiatan - kegiatan yang berhubungan dengan gizi dan aktivitas fisik serta juga dapat membuat majalah dinding (madding) tiap bulannya yang bertemakan gizi dan kesehatan jasmani madding tersebut dapat berisikan promosi PUGS, info mengenai gizi terbaru dan juga laporan hasil skrining kesehatan yang rutin dilakukan puskesmas di SMA Labschool. Madding tersebut dapat diletakkan ditempat - tempat yang strategis seperti kantin, ruang UKS, ruang OSIS, dan di dalam madding tiap - tiap kelas.

$$
\text { Untuk keluarga harus sangat }
$$
memperhatikan konsumsi makanan anak, agar tidak banyak yang mengalami gizi lebih. Melakukan penelitian secara case control atau kualitatif untuk mendapatkan informasi yang lebih mendalam sehingga permasalahan gizi khususnya kebiasaan sarapan dapat dipecahkan dari akar permasalahan yang paling dalam.

\section{Daftar Pustaka}

1. More, Judy. 2014. Gizi Bayi, Anak dan Remaja. Yogyakarta: Pustaka Pelajar Offset.

2. Proverawati, Atikah. 2010. Permasalahan dan perubahan perilaku di kehidupan remaja. Yogyakarta: Nuha medika. 
3. Sulistyoningsih, Hariyani. 2011. Gizi untuk Kesehatan Ibu dan Anak. Edisi Pertama. Yogyakarta: Graha Ilmu.

4. RISKESDAS. 2010. Laporan Riset Kesehatan Dasar. Badan Penelitian dan Pengembangan Kesehatan Kementerian RI. Diunduh pada tanggal 15 Mei 2016.

5. RISKESDAS. 2013. Laporan Riset Kesehatan Dasar. Badan Penelitian dan Pengembangan Kesehatan Kementerian RI. Diunduh pada tanggal 15 Mei 2016.

6. Sarintohe, Prawitasari. 2006. Perilaku makan tidak sehat. Jakarta: Rineka Cipt.

7. Bowman, S. A. 2004. Effect Fast Food Consumption on energy intake and diet quality among children in a national household survey. Pediatric 113:112 - 118.

8. Arisman. 2004. Gizi dalam Daur Kehidupan. Jakarta: Penerbit Buku Kedokteran EGC.

9. Supariasa, I Dewa Nyoman. 2002. Penilaian Status Gizi. Jakarta: EGC.

10. Brown, Judith E.2005. Nutrition Through the Life Cycle Second Edition. USA: Thomson Wadsworth.

11. Utami, Vera Wira. 2012. Hubungan Konsumsi Zat Gizi, Karakteristik Keluarga dan Faktor Lainnya terhadap Remaja Gizi Lebih di SMA N 41 Jakarta Selatan Tahun 2012. Skripsi: FKM UI Depok.

12. Mardhatillah. 2008. Hubungan Kebiasaan Konsumsi Makanan Siap Saji Modern (Fast Food), Aktifitas Fisik dan Faktor Lainnya dengan Kejadian Gizi Lebih pada Remaja SMA Islam Pb. Soedirman di Jakarta Timur. Skripsi. Depok: FKM UI.
13. Rahayuningtyas, Fiky. 2012. Hubungan antara Asupan Serat dan Faktor Lainnya dengan Status Gizi Lebih pada Siswa SMPN 115 Jakarta Selatan. Skripsi: Depok: FKM UI.

14. Hancox, et al. 2004. "Association between Children and Adolescent TV Vieweing and Adult Health: a Longitudinal birth cohort study". Lancet (2004), 364, 257 - 262. Diakses pada tanggal 16 Juni 2016 www.thelancet.com

15. Ortega, et al. 2007. "Physical Activity, Overweight, and Central Adiposity in Swedish Children and Adolescent. The European Heart Study". International Journal of Behavioral Nutrition and Physical Activity, 4(61). Diakses pada tanggal 16 Juni 2016.

16. Patrict, et al. 2004. "Diet, Physical Activity, and Secondary Behaviors as Risk Factors of Overweight in Adolescence". Arch Pediatric Adolescent Medical, 158, 385 - 390. Diakses pada tanggal 16 Juni 2016 dialamat www.jamanetwork.com

17. Khomsan, Ali. 2004. Pangan dan Gizi Untuk Kesehatan. Rajagrafindo Persada; Jakarta. 